\title{
Thermostability of attenuated measles virus vaccine in Pakistan
}

\begin{abstract}
Attenuated measles virus (MV) is an attractive candidate to prevent infectious disease like measles thus making it a safe and effective vaccine available against this can be a fatal disease. In countries like Pakistan having hot and humid climate stability of vaccine, the titre is the important and foremost factor for successful immunization session. Prevalence of measles virus can increase due to the ineffective or poor-quality vaccine. To ensure the quality and efficacy of the vaccine $\mathrm{WHO}$ has taken numerous measures and made guidelines for regulatory authorities. The current study highlights the consistency of measles vaccine at raised temperatures. In this study, 30 batches were tested. The stability studies were carried out on finished products stored at $2-8^{\circ} \mathrm{C}$ and raised the temperature of $37^{\circ} \mathrm{C}$ for seven days in accordance with ICH Guidelines of stability testing of Biological products. This study provides an evaluation of real-time stability shelf life and thermostability studies. The verdicts specify long-term thermostability and verify that this vaccine can remain effectual under the setting of routine use when recommended procedures for storage and handling are tracked in factual essence.
\end{abstract}

Keywords: WHO, immunization, diarrhoea, pneumonia, vaccination
Volume 12 Issue 4 - 2019

\author{
Syeda Shazia Adeel,' Muhammad Babar Taj,' \\ Amina Najam, ${ }^{3}$ Mohammad Asghar, ${ }^{4}$ Rafiq \\ Ahmed Channa, ${ }^{4}$ Tanvir Ibrahim, ${ }^{4}$ Ghazala \\ Parveen ${ }^{4}$ \\ 'Department of Quality Assurance, National Institute of Health, \\ Pakistan \\ ${ }^{2}$ Department of Chemistry, Islamia University of Bahawalpur, \\ Pakistan \\ ${ }^{3}$ Biological Production Division, National Institute of Health, \\ Pakistan \\ ${ }^{4}$ Quality Control Laboratory, National Institute of Health, \\ Pakistan
} Correspondence: Muhammad Babar Taj, Department of
Chemistry, Islamia University of Bahawalpur 63100, Pakistan,
Email drbabartaj@gmail.com

Received: June 06, 2019 | Published: August 29, 2019
Abbreviations: WHO, world health organization; MV, measles virus; MMR, mumps \& rubella; MR, measles-rubella; CCID50, cell culture infected dose; CPE, cytopathic effect

\section{Introduction}

Measles is a highly transmittable disease. In this advanced age of technology and scientific advancements, measles still remains an imperative source of death among young children globally and especially in Pakistan, despite the accessibility to the vaccine. ${ }^{1}$ Children and adults who are unvaccinated are at danger of severe health problems like diarrhoea, pneumonia, blindness and encephalitis (a perilous infection of the brain causing inflammation). The disease can be lethal. ${ }^{2}$

Although global measles deaths have declined by $78 \%$ worldwide; from 562400 deaths in 2000 to 122000 in 2012. In Africa and Asia, measles is a silent mutual prevailing disease. In these parts of the world, almost 20 million people are affected by measles each year The majority (more than 95\%) of measles deaths occur in countries with low per capita incomes and weak health infrastructures. ${ }^{3}$

Use of measles vaccine is in practice since last 50years. The vaccine is effective and low cost. WHO endorses immunization for all children at the ages of 9 and 15 months? This vaccination is done either as measles or measles-rubella (MR), mumps \& rubella (MMR) combination in all national immunization programs. ${ }^{4}$ The intensive and successful vaccination sessions have resulted in a $71 \%$ drop in deaths due to measles between 2000 and 2011, with compact mortality i.e., 1 out of 1,000 . $^{5}$

Pakistan; one of the developing countries and situated in a tropical region with varied temperatures have lost many precious lives to this deadly virus as a result of various outbreaks in many different areas in recent years. ${ }^{7}$ The 14,000 cases of measles were reported in 2012 with 210 patients dying of it. ${ }^{7}$ Despite WHO's new Global Measles \& Rubella Strategic Plan 2012-2020, Vaccination campaigns are not successful and as a result, several outbreaks and deaths have still occurred. ${ }^{5}$ Measles became an annoyance for the health agencies, authorities and common people.

The WHO has taken several measures to reinforce national regulatory authorities and vaccine producers to safeguard the fineness of vaccines used in immunization programmers. It has developed several international standards, which needs to comply until the injection of the vaccine to the patient. ${ }^{8}$

In order to improve the thermostability of measles vaccine extensive studies have been conducted; The modification of an operative stabilizer and the devising of a WHO prerequisite ${ }^{9}$ for heat stability of freeze-dried measles vaccine have made a substantial imprint on the quality of measles vaccines on the market. This requirement uses two directories of stability:

a. The freeze-dried vaccine should retain at least 1000 live virus particles in each human dose at the end of incubation at $37^{\circ} \mathrm{C}$ for seven days; and (2) If during incubation, the virus titre has been reduced, then it shall have done so by not more than $1 \log _{10}$. The increased heat-stability under normal working conditions is especially important in the developing world. ${ }^{9}$

b. In Pakistan National Institute of Health Islamabad is the only public sector organization which is producing Basic Measles vaccine. These studies were carried out on 30 different batches of measles vaccine to know the quality, stability and efficacy of measles vaccine produced by BPD, NIH Pakistan.

\section{Materials and methods}

Individual virus harvest, virus pools before and after filtration $1 \times 2 \mathrm{ml}$ each sample., 4 vials of each sample measles vaccine to be 
tested freeze dried $\left(-20^{\circ} \mathrm{C}\right)$ and at thermal stability samples $\left(37^{\circ} \mathrm{C}\right.$ for 7days), measles virus vaccine reference, medium MEM/199 to which fetal bovine serum and sodium bicarbonate are added, Vero cell suspension, 5\% phenol, trypan blue, Magnetic stirrer, incubator, $\mathrm{CO}_{2}$ incubator, biohazard, inverted microscope, sterile with lids 96well flat bottom microtitration plates, 8-well multichannel pipettor with capacity of $0.025 \mathrm{ml}$ for each well, 12-well multi-channel pipettor with capacity of $0.075 \mathrm{ml}$ for each well, sterile polypropylene tips for pipettor, $0.05 \mathrm{ml}$ pipette droppers $/$ repeater pipettor. Spearman Karber procedure was used to calculate $50 \%$ end-point and cell culture infected dose $\left(\mathrm{CCID}_{50}\right) \cdot \mathrm{CCID}_{50}$ is the virus dilution required to cause infection in $50 \%$ of the total number of inoculated cell cultures.

\section{Preparation of samples}

At least two vials each of freeze-dried vaccine $\left(-20^{\circ} \mathrm{C} \& 37^{\circ} \mathrm{C}\right)$ are reconstituted with $6 \mathrm{ml}$ diluents (Water for Injection) supplied with the vaccine.

\section{Reference vaccine}

NBSCI Edmonstein strains were used as reference vaccines in this study. For each assay one vial of reference vaccine with wellestablished titre is used in this study. The virus samples are diluted in four-fold steps $\left(0.6 \log _{10}\right)$ in 96 -well microtitration plates using 8 well multi-channel pipettors. Four assays are performed in one plate, four wells per dilution, 6 dilutions per titration i.e., $1 / 4$ plate $/$ sample $=24$ wells.

\section{Procedure for setting up test microplates}

$30 \mathrm{ml}$ of test medium is taken in a test reservoir. $0.075 \mathrm{ml}$ of this medium is transferred to each well using multi-channel pipettor. Vero cell suspension used for the test is continuously being stirred upon a magnetic stirrer. Using micro-pipettor add $0.025 \mathrm{ml}$ of starting dilution to every four wells in the first row. If the next four samples are of another sample, then change the tip and add $0.025 \mathrm{ml}$ in the remaining four wells of the first row. The fluid in each well is mixed properly and 6 dilutions are prepared and used tips are discarded in 5\% phenol solution. The lowest dilutions are at the centre of the plate protected from possible dehydration. 50 $\mu 1$ Vero cell suspension (approx. 2.5$3.0 \times 10 \wedge 4$ cells $/ 50 \mu 1 /$ well) Cell control was prepared by using $0.075 \mathrm{ml}$ of diluents followed by $0.05 \mathrm{ml}$ of cell suspension into a row 8 wells. The microtitration plates are sealed with non-adhesive sealer and incubated at $36^{\circ} \mathrm{C}$ for $7-9$ days or without sealing into $\mathrm{CO}_{2}$ incubator for 7-9days. During incubation, cells were monitored to ensure that they were forming a monolayer and did not show any toxicity.

\section{Results and discussion}

Thirty batches of measles test vaccine and reference Vaccine (both Edmonston Zaghreb strain) were tested. Real-time potency was performed on the final product stored at $2-8^{\circ} \mathrm{C}$ while thermostability studies were conducted on product stored at $37^{\circ} \mathrm{C}$. The test was achieved using the WHO method for potency testing of Measles vaccine. ${ }^{10,11}$

The first reading of the microtitration plate for the presence of a cytopathic effect in the form of syncytia (multinucleated giant cells) was observed using an inverted microscope and recording started on the $4^{\text {th }}$ day, the second reading was taken on the $7^{\text {th }}$ day and the final reading was made on the $9^{\text {th }}$ day. During reading each well was examined for specific cytopathic effect (CPE). The test is valid if at least $80 \%$ of cultures are in good condition. The titre of the reference vaccine is within $10^{0.5}$ of the established titre. The loss in titre after incubation at $37^{\circ} \mathrm{C}$ for 7 days should not exceed $1.0 \mathrm{log}$ and the final titre must not be less than $10 \log ^{3} \mathrm{CCID}_{50}$ per human dose. Both conditions must meet. A measles vaccine, upon reconstitution, loses its potency quickly when kept at high temperatures. The effectiveness of reconstituted measles vaccines at $4{ }^{\circ} \mathrm{C}$ persisted above $1000 \mathrm{CCID}_{50}$ for at least 24hours, although the vaccine worsens at a rate of 0.014 $\log 10 \mathrm{CCID}_{50}$ per hour. Use of warm diluent can be injurious; Diluent which is prewarmed at $41{ }^{\circ} \mathrm{C}$ can cause nearly half lost from original potency and resulted in an extra loss in potency to 0.5 to $0.7 \log 10$ after one hour of incubation. At $37^{\circ} \mathrm{C}$ the loss of titre was 0.4 to 0.5 and 0.8 to $1.0 \log 10$ after three and six hours respectively (Figures 1-3). Measles vaccine vial once reconstituted must be must be applied in a single session. To avoid any errors in vaccine handling lyophilized (freeze-dried) vaccine should be reconstituted with diluent provided by the manufacturer. There is a grave danger of efficacy of vaccine when reconstituted measles vaccine is stored for more than six hours at and or above $8^{\circ} \mathrm{C}$. Longer period reconstitution can become a possible source of contamination resulting in serious effects in immunized individuals. At the time of use measles vaccine should always be protected from sunlight and high temperatures. At the end of every vaccination session remaining reconstituted vaccine may always be discarded and should never be kept for next time (Tables 1-3).

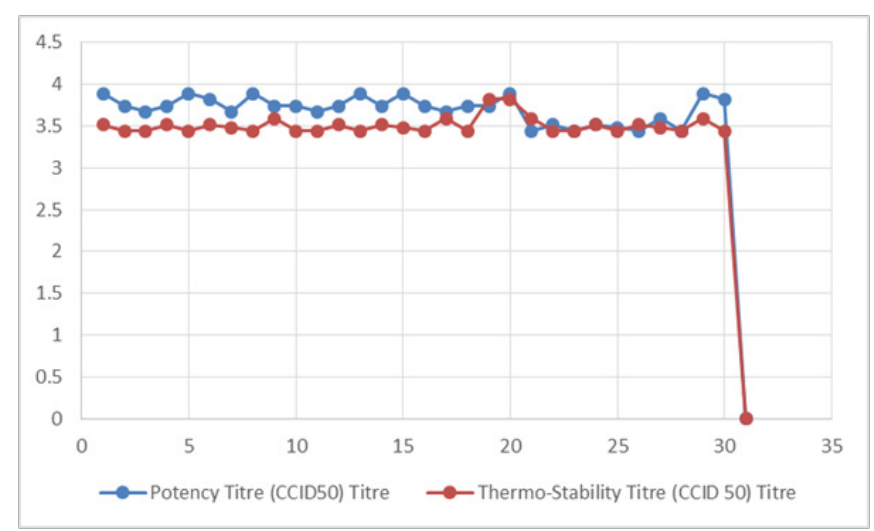

Figure I Range of Potency and thermostability titres of measles vaccine produced at $\mathrm{NIH}$.

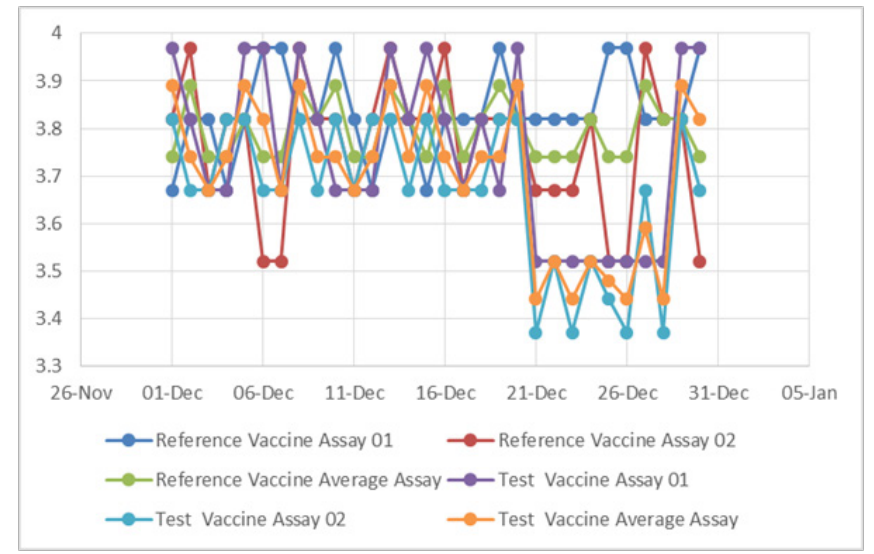

Figure 2 Real-time Potency Test Data $\left(-20^{\circ} \mathrm{C}\right)$ of Measles vaccine. 


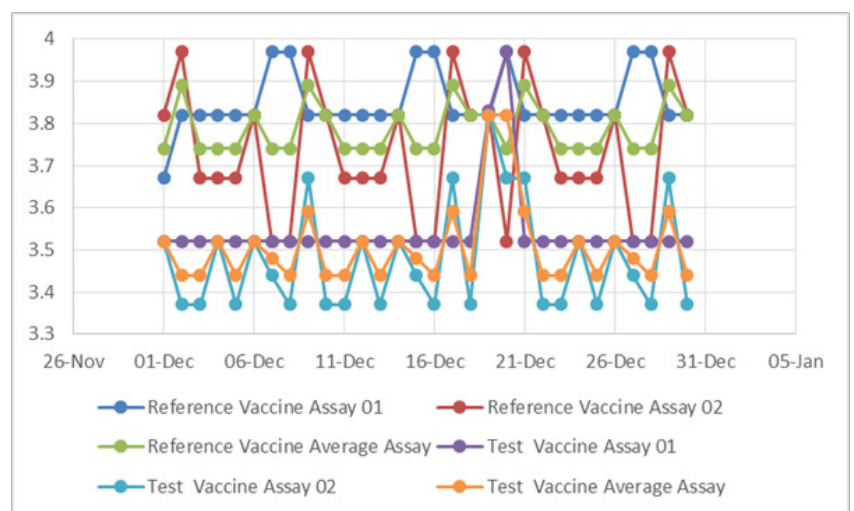

Figure 3 Thermostability Data $\left(37^{\circ} \mathrm{C}\right.$ for 7 days $)$ of Measles vaccine.

Table I Range of Potency and thermostability titres of measles vaccine produced at $\mathrm{NIH}$

\begin{tabular}{llll}
\hline \multicolumn{2}{l}{ Potency titre (CCID50) } & \multicolumn{3}{l}{ Thermo-stability titre (CCID } \\
\hline Batch no & Titre & Batch no & Titre \\
$01-12$ & 3.89 & $01-12$ & 3.52 \\
$02-12$ & 3.74 & $02-12$ & 3.44 \\
$03-12$ & 3.67 & $03-12$ & 3.44 \\
$04-12$ & 3.74 & $04-12$ & 3.52 \\
$05-12$ & 3.89 & $05-12$ & 3.44 \\
$06-12$ & 3.82 & $06-12$ & 3.52 \\
$07-12$ & 3.67 & $07-12$ & 3.48 \\
$08-12$ & 3.89 & $08-12$ & 3.44 \\
$09-12$ & 3.74 & $09-12$ & 3.59 \\
$10-12$ & 3.74 & $10-12$ & 3.44 \\
$11-12$ & 3.67 & $11-12$ & 3.44 \\
$12-12$ & 3.74 & $12-12$ & 3.52 \\
$13-12$ & 3.89 & $13-12$ & 3.44 \\
$14-12$ & 3.74 & $14-12$ & 3.52 \\
$15-12$ & 3.89 & $15-12$ & 3.48 \\
$16-12$ & 3.74 & $16-12$ & 3.44 \\
$17-12$ & 3.67 & $17-12$ & 3.59 \\
$18-12$ & 3.74 & $18-12$ & 3.44 \\
$19-12$ & 3.74 & $19-12$ & 3.82 \\
$20-12$ & 3.89 & $20-12$ & 3.82 \\
$21-12$ & 3.44 & $21-12$ & 3.59 \\
$22-12$ & 3.52 & $22-12$ & 3.44 \\
$23-12$ & 3.44 & $23-12$ & 3.44 \\
$24-12$ & 3.52 & $24-12$ & 3.52 \\
$25-12$ & 3.48 & $25-12$ & 3.44 \\
$26-12$ & 3.44 & $26-12$ & 3.52 \\
$27-12$ & 3.59 & $27-12$ & 3.48 \\
$28-12$ & 3.44 & $28-12$ & 3.44 \\
$29-12$ & 3.89 & $29-12$ & 3.59 \\
$30-12$ & 3.82 & $30-12$ & 3.44 \\
Range & $3.44-3.89$ & Range & -3.82 \\
\hline & & & 3.44 \\
\hline
\end{tabular}

Table 2 Real time Potency Test Data $\left(-20^{\circ} \mathrm{C}\right)$ of Measles vaccine

\begin{tabular}{|c|c|c|c|c|c|c|}
\hline \multirow{3}{*}{$\begin{array}{l}\text { Batch } \\
\# \\
01-12\end{array}$} & \multicolumn{3}{|c|}{ Reference vaccine } & \multicolumn{3}{|c|}{ Test vaccine } \\
\hline & $\begin{array}{l}\text { Assay } \\
01\end{array}$ & $\begin{array}{l}\text { Assay } \\
02\end{array}$ & $\begin{array}{l}\text { Average } \\
\text { assay }\end{array}$ & $\begin{array}{l}\text { Assay } \\
01\end{array}$ & $\begin{array}{l}\text { Assay } \\
02\end{array}$ & $\begin{array}{l}\text { Average } \\
\text { assay }\end{array}$ \\
\hline & 3.67 & 3.82 & 3.74 & 3.97 & 3.82 & 3.89 \\
\hline $02-12$ & 3.82 & 3.97 & 3.89 & 3.82 & 3.67 & 3.74 \\
\hline $03-12$ & 3.82 & 3.67 & 3.74 & 3.67 & 3.67 & 3.67 \\
\hline $04-12$ & 3.67 & 3.82 & 3.74 & 3.67 & 3.82 & 3.74 \\
\hline $05-12$ & 3.82 & 3.82 & 3.82 & 3.97 & 3.82 & 3.89 \\
\hline $06-12$ & 3.97 & 3.52 & 3.74 & 3.97 & 3.67 & 3.82 \\
\hline $07-12$ & 3.97 & 3.52 & 3.74 & 3.67 & 3.67 & 3.67 \\
\hline $08-12$ & 3.82 & 3.97 & 3.89 & 3.97 & 3.82 & 3.89 \\
\hline $09-12$ & 3.82 & 3.82 & 3.82 & 3.82 & 3.67 & 3.74 \\
\hline $10-12$ & 3.97 & 3.82 & 3.89 & 3.67 & 3.82 & 3.74 \\
\hline $11-12$ & 3.82 & 3.67 & 3.74 & 3.67 & 3.67 & 3.67 \\
\hline $12-12$ & 3.67 & 3.82 & 3.74 & 3.67 & 3.82 & 3.74 \\
\hline $13-12$ & 3.82 & 3.97 & 3.89 & 3.97 & 3.82 & 3.89 \\
\hline $14-12$ & 3.82 & 3.82 & 3.82 & 3.82 & 3.67 & 3.74 \\
\hline $15-12$ & 3.67 & 3.82 & 3.74 & 3.97 & 3.82 & 3.89 \\
\hline $16-12$ & 3.82 & 3.97 & 3.89 & 3.82 & 3.67 & 3.74 \\
\hline $17-12$ & 3.82 & 3.67 & 3.74 & 3.67 & 3.67 & 3.67 \\
\hline $18-12$ & 3.82 & 3.82 & 3.82 & 3.82 & 3.67 & 3.74 \\
\hline $19-12$ & 3.97 & 3.82 & 3.89 & 3.67 & 3.82 & 3.74 \\
\hline $20-12$ & 3.82 & 3.82 & 3.82 & 3.97 & 3.82 & 3.89 \\
\hline $21-12$ & 3.82 & 3.67 & 3.74 & 3.52 & 3.37 & 3.44 \\
\hline $22-12$ & 3.82 & 3.67 & 3.74 & 3.52 & 3.52 & 3.52 \\
\hline $23-12$ & 3.82 & 3.67 & 3.74 & 3.52 & 3.37 & 3.44 \\
\hline $24-12$ & 3.82 & 3.82 & 3.82 & 3.52 & 3.52 & 3.52 \\
\hline $25-12$ & 3.97 & 3.52 & 3.74 & 3.52 & 3.44 & 3.48 \\
\hline $26-12$ & 3.97 & 3.52 & 3.74 & 3.52 & 3.37 & 3.44 \\
\hline $27-12$ & 3.82 & 3.97 & 3.89 & 3.52 & 3.67 & 3.59 \\
\hline $28-12$ & 3.82 & 3.82 & 3.82 & 3.52 & 3.37 & 3.44 \\
\hline $29-12$ & 3.82 & 3.82 & 3.82 & 3.97 & 3.82 & 3.89 \\
\hline $30-12$ & 3.97 & 3.52 & 3.74 & 3.97 & 3.67 & 3.82 \\
\hline
\end{tabular}

Table 3 Thermo stability Data $\left(37^{\circ} \mathrm{C}\right.$ for 07 days) of Measles vaccine

\begin{tabular}{lllllll}
\hline & \multicolumn{3}{l}{ Reference vaccine } & \multicolumn{3}{l}{ Test vaccine } \\
\cline { 2 - 7 } \begin{tabular}{l} 
Batch \\
\cline { 2 - 7 }
\end{tabular} & $\begin{array}{l}\text { Assay } \\
\text { OI }\end{array}$ & $\begin{array}{l}\text { Assay } \\
\mathbf{0 2}\end{array}$ & $\begin{array}{l}\text { Average } \\
\text { assay }\end{array}$ & $\begin{array}{l}\text { Assay } \\
\text { OI }\end{array}$ & $\begin{array}{l}\text { Assay } \\
\text { 02 }\end{array}$ & $\begin{array}{l}\text { Average } \\
\text { assay }\end{array}$ \\
\cline { 2 - 7 } $01-12$ & 3.67 & 3.82 & 3.74 & 3.52 & 3.52 & 3.52 \\
$02-12$ & 3.82 & 3.97 & 3.89 & 3.52 & 3.37 & 3.44 \\
$03-12$ & 3.82 & 3.67 & 3.74 & 3.52 & 3.37 & 3.44 \\
$04-12$ & 3.82 & 3.67 & 3.74 & 3.52 & 3.52 & 3.52 \\
$05-12$ & 3.82 & 3.67 & 3.74 & 3.52 & 3.37 & 3.44 \\
$06-12$ & 3.82 & 3.82 & 3.82 & 3.52 & 3.52 & 3.52 \\
$07-12$ & 3.97 & 3.52 & 3.74 & 3.52 & 3.44 & 3.48 \\
$08-12$ & 3.97 & 3.52 & 3.74 & 3.52 & 3.37 & 3.44 \\
$09-12$ & 3.82 & 3.97 & 3.89 & 3.52 & 3.67 & 3.59 \\
\hline
\end{tabular}


Table Continues..

\begin{tabular}{|c|c|c|c|c|c|c|}
\hline \multirow[b]{2}{*}{$\begin{array}{l}\text { Batch } \\
\#\end{array}$} & \multicolumn{3}{|c|}{ Reference vaccine } & \multicolumn{3}{|c|}{ Test vaccine } \\
\hline & $\begin{array}{l}\text { Assay } \\
\text { 0I }\end{array}$ & $\begin{array}{l}\text { Assay } \\
02\end{array}$ & $\begin{array}{l}\text { Average } \\
\text { assay }\end{array}$ & $\begin{array}{l}\text { Assay } \\
\text { 0I }\end{array}$ & $\begin{array}{l}\text { Assay } \\
02\end{array}$ & $\begin{array}{l}\text { Average } \\
\text { assay }\end{array}$ \\
\hline $10-12$ & 3.82 & 3.82 & 3.82 & 3.52 & 3.37 & 3.44 \\
\hline $11-12$ & 3.82 & 3.67 & 3.74 & 3.52 & 3.37 & 3.44 \\
\hline $12-12$ & 3.82 & 3.67 & 3.74 & 3.52 & 3.52 & 3.52 \\
\hline $13-12$ & 3.82 & 3.67 & 3.74 & 3.52 & 3.37 & 3.44 \\
\hline $14-12$ & 3.82 & 3.82 & 3.82 & 3.52 & 3.52 & 3.52 \\
\hline $15-12$ & 3.97 & 3.52 & 3.74 & 3.52 & 3.44 & 3.48 \\
\hline $16-12$ & 3.97 & 3.52 & 3.74 & 3.52 & 3.37 & 3.44 \\
\hline $17-12$ & 3.82 & 3.97 & 3.89 & 3.52 & 3.67 & 3.59 \\
\hline $18-12$ & 3.82 & 3.82 & 3.82 & 3.52 & 3.37 & 3.44 \\
\hline $19-12$ & 3.82 & 3.82 & 3.82 & 3.83 & 3.82 & 3.82 \\
\hline $20-12$ & 3.97 & 3.52 & 3.74 & 3.97 & 3.67 & 3.82 \\
\hline $21-12$ & 3.82 & 3.97 & 3.89 & 3.52 & 3.67 & 3.59 \\
\hline $22-12$ & 3.82 & 3.82 & 3.82 & 3.52 & 3.37 & 3.44 \\
\hline $23-12$ & 3.82 & 3.67 & 3.74 & 3.52 & 3.37 & 3.44 \\
\hline $24-12$ & 3.82 & 3.67 & 3.74 & 3.52 & 3.52 & 3.52 \\
\hline $25-12$ & 3.82 & 3.67 & 3.74 & 3.52 & 3.37 & 3.44 \\
\hline $26-12$ & 3.82 & 3.82 & 3.82 & 3.52 & 3.52 & 3.52 \\
\hline $27-12$ & 3.97 & 3.52 & 3.74 & 3.52 & 3.44 & 3.48 \\
\hline $28-12$ & 3.97 & 3.52 & 3.74 & 3.52 & 3.37 & 3.44 \\
\hline $29-12$ & 3.82 & 3.97 & 3.89 & 3.52 & 3.67 & 3.59 \\
\hline $30-12$ & 3.82 & 3.82 & 3.82 & 3.52 & 3.37 & 3.44 \\
\hline
\end{tabular}

\section{Conclusion}

Lypholized measles vaccine is a stable product when kept at $0^{\circ} \mathrm{C}$. Freezing and refreezing does not damage the efficacy of the vaccine. Stored at an optimum temperature of $2^{\circ} \mathrm{C}$ and $8^{\circ} \mathrm{C}$ lypholized vaccine always maintain the minimum potency given by the manufacturer i.e., up to two years. At room temperature $\left(20^{\circ} \mathrm{C}\right.$ to $\left.25^{\circ} \mathrm{C}\right)$ the least compulsory infectivity titre of measles virus can be retained for one month and even at $37^{\circ} \mathrm{C}$ the vaccine can continue its minimum effectiveness. But at $41^{\circ} \mathrm{C}$ vaccine degrades fast and shows a decrease in titre up to $50 \%$ within 48 hours. The loss in potency is very evident once the vaccine is reconstituted and kept at elevated temperatures or for longer periods. Potency reduction is very evident at elevated temperatures; at $26^{\circ} \mathrm{C}$ it takes only 16 hours to reach the minimum level of potency. When the reconstituted vaccine is kept at $37^{\circ} \mathrm{C}$ it reaches its lowest in just one hour. Manufacturer guidelines must strictly be followed during the immunization process and must always be kept at recommended temperatures and should never be left for the next session.

\section{Acknowledgments}

None.

\section{Conflicts of interest}

The authors declare that there are no conflicts of interest.

\section{Funding}

None.

\section{References}

1. Oliwa JN, Marais BJ. Vaccines to prevent pneumonia in children-a developing country perspective. Paediatr Respir Rev. 2017;22:23-30.

2. World Health Organization (WHO). Immunization Immunization in practice: A practical guide for health staff. Geneva: World Health Organization. 2015.

3. Ter Meulen, Volker Ter, Bach, et al. Bach Measles virus. Springer. 2012.

4. Williams WW, Hickson MA, Kane MA, et al. Immunization policies and vaccine coverage among adults: the risk for missed opportunities. Ann Intern Med. 1988;108(4):616-25.

5. Khan T, Qazi J. Measles outbreaks in Pakistan: causes of the tragedy and future implications. Epidemiology Reports. 2014;2:1.

6. World Health Organization (WHO). Organization Hidden Cities: unmasking and overcoming health inequities in urban settings. Geneva: World Health Organization; 2010.

7. Niazi A, Sadaf R. Measles Epidemic in Pakistan: In Search of Solutions. Ann Med Health Sci Res. 2014;4(1):1-2.

8. Pécoul B, Chirac P, Trouiller P, et al. Access to essential drugs in poor countries: a lost battle? JAMA. 1999;281(4):361-367.

9. Milstien JB, Galazka U, Kartoglu M, et al. Temperature sensitivity of vaccines. Geneva: World Health Organization; 2006.

10. Schwarz AJ. Preliminary tests of a highly attenuated measles vaccine. $A m$ J Dis Child. 1962;103:386-389.

11. Hendriksen C, Spieser JM, Akkermans A, et al. Validation of alternative methods for the potency testing of vaccines. Altern Lab Anim. 1998;26(6):747-761. 